\title{
HOUSING INTEGRATION OF IMMIGRANTS IN VIENNA - EQUAL OPPORTUNITIES?
}

\author{
Josef Kohlbacher and Ursula Reeger
}

\section{Vienna's Migrant Population and its Characteristics}

Vienna's telephone directory is testimony to its long immigration history. In 1900, $60 \%$ of the Viennese population were Czechs, Slovaks, Hungarians, or Poles from the Eastern parts of the Empire. During the economic boom of the 1960s Vienna again became a focal point of labour migration. The "guest-workers" were recruited on the basis of bilateral agreements with Turkey (1964) and Yugoslavia (1966). In 1969, the number of guest-workers stood at 76,500, Vienna and Vorarlberg attracting the majority of them. By 1973, the number of guest-workers had almost tripled to 227,000, of whom 178,000 came from Yugoslavia and 27,000 from Turkey. As a response to the recession in the early 1970 s, the guest-worker recruitment was abolished. Then, in 1985, the employment of Yugoslav and Turkish citizens was only half the level of 1973 (Fassmann \& Münz 1995). The guest-worker migration of the 1960s has had permanent effects on the composition of the foreign resident population in Vienna. According to official data, about $47 \%$ of Vienna's foreign resident population in 2007 came from the two traditional recruitment regions of guest-workers, ex-Yugoslavia and Turkey. Further, in 2007 242,088 out of a total of 538,256 residents had a (primary, secondary, or tertiary) migration background related to the former guest-worker migration of the 1960s and 1970s (Statistics Austria, Population register, revised by MA6).

As a result of the fall of the Iron Curtain and Austria's accession to the European Union, Vienna moved from being at a marginal geographical position in Europe to its centre. This brought a rise in temporary migration as well as transnational mobility. Furthermore, family reunification, clandestine migration, and asylum migration became increasingly important. The Balkan Wars produced a massive inflow of refugees into Austria, who came in addition to the rising numbers of asylum seekers. In 1990 Austria enacted a regularization of the employment status of hitherto illegally employed foreigners (Fassmann \& Münz 1995, John 2003). The number of non-nationals in Vienna then rose sharply from 152,935 in 1988 to 230,284 in 1993, an increase in the share of the foreign population from $9.1 \%$ to $14.9 \%$. 
Table 5: Residential population of Vienna 1980-2007

\begin{tabular}{|c|c|c|c|c|c|c|c|}
\hline & total & & & strians & foreig & n citizens & share of \\
\hline & population & $1980=100$ & abs. & $1980=100$ & abs. & $1980=100$ & foreigners \\
\hline 1980 & $1,535,145$ & 100.0 & $1,424,405$ & 100.0 & 110,740 & 100.0 & 7.2 \\
\hline 1981 & $1,528,631$ & 99.6 & $1,412,376$ & 99.2 & 116,255 & 105.0 & 7.6 \\
\hline 1982 & $1,510,634$ & 98.4 & $1,399,450$ & 98.2 & 111,184 & 100.4 & 7.4 \\
\hline 1983 & $1,499,866$ & 97.7 & $1,389,870$ & 97.6 & 109,996 & 99.3 & 7.3 \\
\hline 1984 & $1,494,874$ & 97.4 & $1,381,875$ & 97.0 & 112,999 & 102.0 & 7.6 \\
\hline 1985 & $1,490,956$ & 97.1 & $1,373,686$ & 96.4 & 117,270 & 105.9 & 7.9 \\
\hline 1986 & $1,485,484$ & 96.8 & $1,366,157$ & 95.9 & 119,327 & 107.8 & 8.0 \\
\hline 1987 & $1,484,258$ & 96.7 & $1,359,760$ & 95.5 & 124,498 & 112.4 & 8.4 \\
\hline 1988 & $1,485,777$ & 96.8 & $1,350,020$ & 94.8 & 135,757 & 122.6 & 9.1 \\
\hline 1989 & $1,492,636$ & 97.2 & $1,339,701$ & 94.1 & 152,935 & 138.1 & 10.2 \\
\hline 1990 & $1,502,772$ & 97.9 & $1,330,837$ & 93.4 & 171,935 & 155.3 & 11.4 \\
\hline 1991 & $1,522,449$ & 99.2 & $1,325,120$ & 93.0 & 197,329 & 178.2 & 13.0 \\
\hline 1992 & $1,537,523$ & 100.2 & $1,320,648$ & 92.7 & 216,875 & 195.8 & 14.1 \\
\hline 1993 & $1,549,436$ & 100.9 & $1,319,152$ & 92.6 & 230,284 & 208.0 & 14.9 \\
\hline 1994 & $1,542,667$ & 100.5 & $1,311,953$ & 92.1 & 230,714 & 208.3 & 15.0 \\
\hline 1995 & $1,539,002$ & 100.3 & $1,305,009$ & 91.6 & 233,993 & 211.3 & 15.2 \\
\hline 1996 & $1,542,191$ & 100.5 & $1,305,758$ & 91.7 & 236,433 & 213.5 & 15.3 \\
\hline 1997 & $1,540,875$ & 100.4 & $1,304,955$ & 91.6 & 235,920 & 213.0 & 15.3 \\
\hline 1998 & $1,542,252$ & 100.5 & $1,303,518$ & 91.5 & 238,734 & 215.6 & 15.5 \\
\hline 1999 & $1,548,537$ & 100.9 & $1,305,870$ & 91.7 & 242,667 & 219.1 & 15.7 \\
\hline 2000 & $1,553,956$ & 101.2 & $1,306,287$ & 91.7 & 247,669 & 223.6 & 15.9 \\
\hline 2001 & $1,562,737$ & 101.8 & $1,308,044$ & 91.8 & 254,693 & 230.0 & 16.3 \\
\hline 2002 & $1,583,814$ & 103.2 & $1,314,932$ & 92.3 & 268,882 & 242.8 & 17.0 \\
\hline 2003 & $1,598,626$ & 104.1 & $1,321,662$ & 92.8 & 276,964 & 250.1 & 17.3 \\
\hline 2004 & $1,626,440$ & 105.9 & $1,333,084$ & 93.6 & 293,356 & 264.9 & 18.0 \\
\hline 2005 & $1,651,438$ & 107.6 & $1,342,254$ & 94.2 & 309,184 & 279.2 & 18.7 \\
\hline 2006 & $1,657,559$ & 108.0 & $1,345,196$ & 94.4 & 312,363 & 282.1 & 18.8 \\
\hline 2007 & $1,670,749$ & 108.8 & $1,345,798$ & 94.5 & 324,951 & 293.4 & 19.4 \\
\hline
\end{tabular}

Sources: Statistics Austria - residential population according to population prognosis (Bevölkerungsfortschreibung), own calculations.

Vienna's population has become even more diverse in recent years. Now, onethird of the entire Viennese population has a migration background (i.e., either they 
themselves or their parents were born abroad), and $40 \%$ of the foreign nationals living in the city do not come from the classical countries of origin. Nevertheless, public consciousness mostly completely ignores the fact that Vienna is a traditional focus of immigration - and national immigration policy reflects that ambivalence. The policy of the Municipality of Vienna is by many accounts much more conscious of the importance of immigration and the integration of migrants, though the local policy is partially determined by national legislation.

Table 5 shows the variations in the numbers and proportions of legal foreign residents in the Viennese population from 1980 to 2007. By the end of 2007, there were $1,670,749$ residents in Vienna, including 324.951 foreign nationals, $19.4 \%$ of the entire Viennese population. A constant increase in the proportion of non-Austrian citizens has been observed. The percentage rose from about $7 \%$ or $8 \%$ during the 1980 s to between $10 \%$ and $15 \%$ during the 1990 s, reaching its peak in 2007 , when $19.4 \%$ of Vienna's population consisted of foreign nationals. The absolute number of foreign residents in 2005 was three times higher than in 1980, and in 2007 the index value was 293.4. Following a period of stagnation or even nominal decrease in the overall population during the 1980 s, primarily the positive migration balance has caused an increase of Vienna's population since the 1990s. And the positive demographic trend still goes on - Vienna is one of the very few Austrian federal provinces with rising birthrates (though there was a decrease during the first half of 2009) and increasing numbers of children in schools and kindergartens.

Table 6 shows the variations in the structure of the migrant population by geographical descent. In 2007, more than $68 \%$ of all foreign nationals came from European countries (EU and former Yugoslavia). The most numerous group was that of the former guest-workers who constituted $47 \%$ of the total foreign population in 2007. About 116,000 persons (34.9\%) came from former Yugoslavia, and about 40,000 $(12.1 \%)$ were from Turkey. With more than 66,000 persons $(20 \%)$ East-West migrants form another numerically important component of the immigrant population, the Poles being the greatest group. Middle- and upper-class migrants stem mainly from Germany, other EU-14 countries, or from North America, and often are only temporary migrants there for business or studies. In 2007 , more than $7 \%$ of the migrant stock consisted of EU-14 citizens. Compared to 2001, the number of German nationals has almost doubled. The number of citizens coming from the EU-10 (accessed 2004) and EU-2 (accessed 2007) countries were on the increase throughout this period. Migrants from Asia, Africa, South America, and the Middle East still constitute nominally smaller groups, but their numbers grew significantly from 2006 to 2007. Egyptians make up the largest African group, followed by Nigerians. The most prominent Asian countries of origin are China, India, Iran, and the Philippines. The number of immigrants from India, for example, rose from 624 in 1981 to 4,678 in 2007 - almost eight times more. In 2007 there were eleven times more Chinese living in Vienna than in 1981 and about three times more Filipinos. 
Table 6: Structure of the foreign residential population in Vienna 1981-2007

\begin{tabular}{|c|c|c|c|c|c|c|c|c|}
\hline Nationality & 1981 & 1991 & 2001 & 2004 & 2005 & 2006 & 2007 & $\begin{array}{r}\text { Varia- } \\
\text { tion } \\
2006 / 07\end{array}$ \\
\hline "Guest-worker" & 78,297 & 131,234 & 153,428 & 157,090 & 159,557 & 156,759 & 156,194 & -1.4 \\
\hline Former Yugoslavia & 58,587 & 87,358 & 114,811 & 117,362 & 119,656 & 117,606 & 116,057 & -1.3 \\
\hline Turkey & 19,710 & 43,876 & 38,617 & 39,728 & 39,901 & 39,153 & 40,137 & +2.5 \\
\hline East-West migration & 5,528 & 21,907 & 31,256 & 46,266 & 52,491 & 59,390 & 66,111 & +11.3 \\
\hline Poland & 2,653 & 11,056 & 13,646 & 18,258 & 21,610 & 24,111 & 25,618 & +6.3 \\
\hline Hungary & 1,117 & 3,539 & 4,149 & 4,941 & 5,271 & 5,702 & 6,422 & +12.6 \\
\hline Czech Republic $^{1}$ & 753 & 2,619 & 1,839 & 2,224 & 2,362 & 2,527 & 2,645 & +4.7 \\
\hline Slovakia & - & - & 3,300 & 5,427 & 6,360 & 7,096 & 7,697 & +8.5 \\
\hline Romania & 350 & 2,532 & 3,809 & 6,961 & 7,796 & 8,032 & 10,196 & +26.9 \\
\hline GUS $^{2}$ & 417 & 1,357 & 2,096 & 4,366 & 4,741 & 7,413 & 8,200 & +10.6 \\
\hline Bulgaria & 238 & 804 & 2,417 & 4,089 & 4,351 & 4,509 & 5,333 & $+18,3$ \\
\hline EU-14 & - & - & 26,243 & 34,178 & 37,776 & 41,091 & 44,972 & $+9,4$ \\
\hline Germany & 6,374 & 9,017 & 13,398 & 18,094 & 20,417 & 22,766 & 25,404 & $+11,6$ \\
\hline Other EU-14 countries & - & - & 12,845 & 16,084 & 17,359 & 18,325 & 19,568 & +6.8 \\
\hline Africa & 3,909 & 7,179 & 8,313 & 8,629 & 8,542 & 12,318 & 11,764 & $-4,5$ \\
\hline Egypt & 1,003 & 2,736 & 3,067 & 3,121 & 3,240 & 3,215 & 3,357 & $+4,4$ \\
\hline Asian Countries & 2,770 & 6,694 & 10,129 & 13,623 & 14,463 & 31,697 & $\mathbf{3 3 , 5 3 3}$ & $+5,8$ \\
\hline India & 624 & 2,008 & 3,778 & 4,425 & 4,615 & 4,620 & 4,678 & $+1,3$ \\
\hline Philippines & 981 & 1,842 & 2,157 & 2,646 & 2,870 & 3,020 & 3,166 & $+4,8$ \\
\hline Iran & 2,096 & 3,088 & 4,055 & 4,210 & 4,026 & 4,249 & 4,624 & $+8,8$ \\
\hline Peoples Republic of China & 510 & 1,770 & 3,025 & 5,188 & 5,557 & 5,640 & 5,837 & $+3,5$ \\
\hline USA and Canada & 2,218 & 2,600 & 3,096 & 3,562 & 3,827 & 6,307 & 7,659 & $+21,4$ \\
\hline Others & 14,321 & 18,021 & 22,228 & 30,008 & 32,528 & 10,429 & 11,967 & +14.7 \\
\hline Foreign nationals total & 113,417 & 196,652 & 254,693 & 293,356 & 309,184 & 317,991 & 332,200 & +4.5 \\
\hline
\end{tabular}

1: 1981, 1991 Czechoslovakia; 2: 1981, 1991 Soviet Union, 2006, 2007: Russian Federation + Ukraine.

Source: 1981, 1991: Census data, Statistics Austria, since 2001: Population Register.

The overall age structure of migrants is much younger than that of the local population because of labour migration and some remigration in later phases of life. The gender balance varies considerably from one group to the other. Immigration from Slovakia and the Czech Republic consisted by far of women, whereas Polish migration was more a male phenomenon. Among Black Africans the proportion of women 
is extremely modest (35\%) (Ebermann 2007). Migrants from Asian countries tend toward a higher female proportion (46\%). Especially among the Chinese, the Filipinos and the Indian subgroup from Kerala is the number of women an important factor.

Specific niches in the labour market are more or less "reserved" for migrants of specific ethno-national affiliation. Turkish women, for example, do cleaning jobs, Polish women work in domestic services, Philippine and Indian women can be found in health service, Egyptians and Bangladeshi sell newspapers, Turkish and Polish men are well represented in the construction business, and Chinese traditionally run restaurants. The economic crisis of 2008/09 brought an increase in unemployment in almost all economic sectors and some remigration of temporary labour migrants. The level of unemployment in Vienna is now higher than in some western regions of Austria, and migrants have been particularly hard hit (Integrationsfonds 01/2009).

\section{Housing Stock and Housing Market in General}

The Viennese housing market has a long tradition of communal intervention and social engineering. The still partially existing system of security of tenure was introduced at the end of World War I. The principle of respecting the tenants' rights was then transformed into law in the 1920s. At the time the promotion of housing construction via a special tax system existed only in the city of Vienna. More than 60,000 community-owned apartments were built by the "Red Vienna" during the "First Republic" (1919-1938) alone. For several decades after the Second World War Vienna's housing policy was based on the corporatist system of "social partnership," a typical Austrian institution. Since the 1990s housing policy has become more market-oriented (Lichtenberger 1990).

The Viennese housing market consists of the following main components (Fassmann et al. 2002):

- Private rental housing: particularly in the Founding Period ("Gründerzeit," 1870s) building stock. The buildings are mostly private owned or owned by companies. The rents are calculated on the basis of a complicated system, which depends on the standard of the flat and its location. Long-term regulation of private rental housing has reduced the share of this sector, but it still dominates the stock. Tenancy agreements are legally based on the law governing tenancy rights (MRG, "Mietrechtsgesetz").

- Protected rental housing: can be found today only in buildings constructed earlier than 1917, a special kind of apartement house with very modest rent and a low tenant mobility. This segment is dying out with the death of the old tenants.

- Council housing: Public housing has a long tradition in Vienna and in fact forms part of the city's identity. The City of Vienna is not only in Austria but also in Europe the biggest owner of residences with modest rents (Förster 2002a, b): about 220,000 apartments. The municipal residences of the early $20^{\text {th }}$ century are nowadays mostly renovated. Rents usually rise after renovation but are still lower than in the 
private rental sector. Over the past few years the construction of new communal housing blocks has been reduced. In Vienna 31\% (in Austria: about 10\%) of the population live in communal housing. Most public housing flats are located in the larger districts $\left(10^{\text {th }}, 21^{\text {st }}, 22^{\text {nd }}\right)$, but one can find public housing in every district. Before 1 January 2006 there was almost no admission of foreign citizens to this segment (exceptions: EC citizens, refugees with asylum status, other third-country nationals held equal to nationals).

- Co-operative housing: This type was built up in the newly developed areas of the outer city as well as on existing small lots of the developed area of the inner city from the Founding Period. In Vienna about $13 \%$ of the residential population lives in this type of housing. The housing associations are financially supported by public money or funds. Experimental projects, such as car-free projects, women's workshops I and II, integration projects, and passive houses strive to further improve housing quality.

- Owner-occupied housing: This is an increasing segment of the Viennese housing market. In Vienna only $17 \%$ of the population live in owner-occupied houses, as opposed to Austria as a whole where the proportion is more than $50 \%$. The overwhelming majority of inhabitants in the owner-occupied housing sector are Austrian citizens (2001: 97\%).

Table 7: Ownership structure of building stock and flats in Vienna, 2001

\begin{tabular}{lrrrr}
\hline Legal ownership & Buildings & in \% & Flats & in \% \\
\hline Private person(s) & 112,281 & 66.8 & 475,423 & 52.2 \\
Municipality & 26,028 & 15.5 & 231,881 & 25.5 \\
Co-operative & 15,741 & 9.3 & 121,559 & 13.3 \\
Other & 14,117 & 8.4 & 81,882 & 9.0 \\
Total & 168,167 & 100.0 & 910,745 & 100.0 \\
\hline
\end{tabular}

Source: Census 2001.

Housing construction in Vienna was accelerated substantially in the second half of the 1990s in response to the rise in the immigrant population. The number of housing units surged from 1990 to the end of 2002 by a total of $9.2 \%$ to 929,878 units. In the years 1994 to 2000, for example, housing construction generated an average of 10,000 subsidized and some 1,000 to 1,500 nonsubsidized housing units per year. After the year 2000, however, construction output dropped to approximately 6,000 housing units per year. The reduced construction activity of recent years has now translated into a stronger demand for subsidised rental housing construction. Waiting lists for public housing are generally long, and it can take up to 2 years to get an apartment in this segment. In general, the quality demands have clearly risen among all social segments. There is also a rising consciousness about saving energy, which means that the use of new energy-efficient building technologies has increased the costs of new buildings. 
Table 8: Level of equipment of apartments in Vienna (1981, 1991 and 2001 compared)

\begin{tabular}{lrrrr}
\hline & 1981 & 1991 & 2001 & $1981=100$ \\
\hline with bathroom/shower and central heating & 248,927 & 513,743 & 680,148 & 273.2 \\
with bathroom and shower & 256,958 & 102,463 & 62,920 & 24.5 \\
with toilet and water supply inside & 77,431 & 47,998 & 11,869 & 15.3 \\
with water supply inside & 85,401 & 52,746 & 13,650 & 16.0 \\
without inside water supply & 48,891 & 22,012 & 2,368 & 4.8 \\
Total & 717,608 & 738,962 & 770,955 & 107.4 \\
\hline
\end{tabular}

Source: Census 1981, 1991, 2001.

Table 8 illustrates how the equipment standard of flats changed from 1981 to 2001 . The upper standard category with bathroom and central heating doubled between 1981 and 1991 and almost tripled up to 2001. During the same period the worst category decreased from about 49,000 to 2,400 units. A marked shrinking process could also be observed in all the categories having no central heating. By 2001, 14.2\% $(23,866)$ of all houses in Vienna had gotten new windows, 9.5\% a new roof, $4.2 \%$ central heating, $7.9 \%$ new facades with heat insulation and $9.6 \%$ a channel interface. $82.8 \%$ of all residences lived in Category A accommodation (more than $30 \mathrm{~m}^{2}$, bathroom, kitchen, toilet, running hot and cold water, and heating), $6.8 \%$ in Category B (bathroom, toilet, kitchen), $2.1 \%$ still had a toilet and running water within the rooms (Category C), and $8.3 \%$ had no toilet or running water (Category D).

The rent level shows marked variations, which depend on the location and the district's image. Residences in the inner city and in districts 13,18 , and 19 are the most attractive both for rental housing and home ownership, the highest being the $6^{\text {th }}$ district, followed by the $7^{\text {th }}$ and $8^{\text {th }}$. The $8^{\text {th }}$ district is a small but classy district, and the price level in the housing sector sharply increased because of short supply. The $6^{\text {th }}$ district, being one of the most preferred districts, is still affordable compared to some of the other inner districts. Low priced are the rental flats in the $5^{\text {th }}, 20^{\text {th }}, 12^{\text {th }}$ and $10^{\text {th }}$ district.

\section{Housing Situation of Residents with Migration Background}

\subsection{Inner City Distribution}

For decades the easiest access to the local housing market for migrants in Vienna was in the Founding Period rental segment, which is mainly concentrated in the inner districts and the former working-class districts along the "Belt" ("Gürtel"). Thus, the 
Map 4: Proportion of foreign residents in Vienna's statistical districts 1991

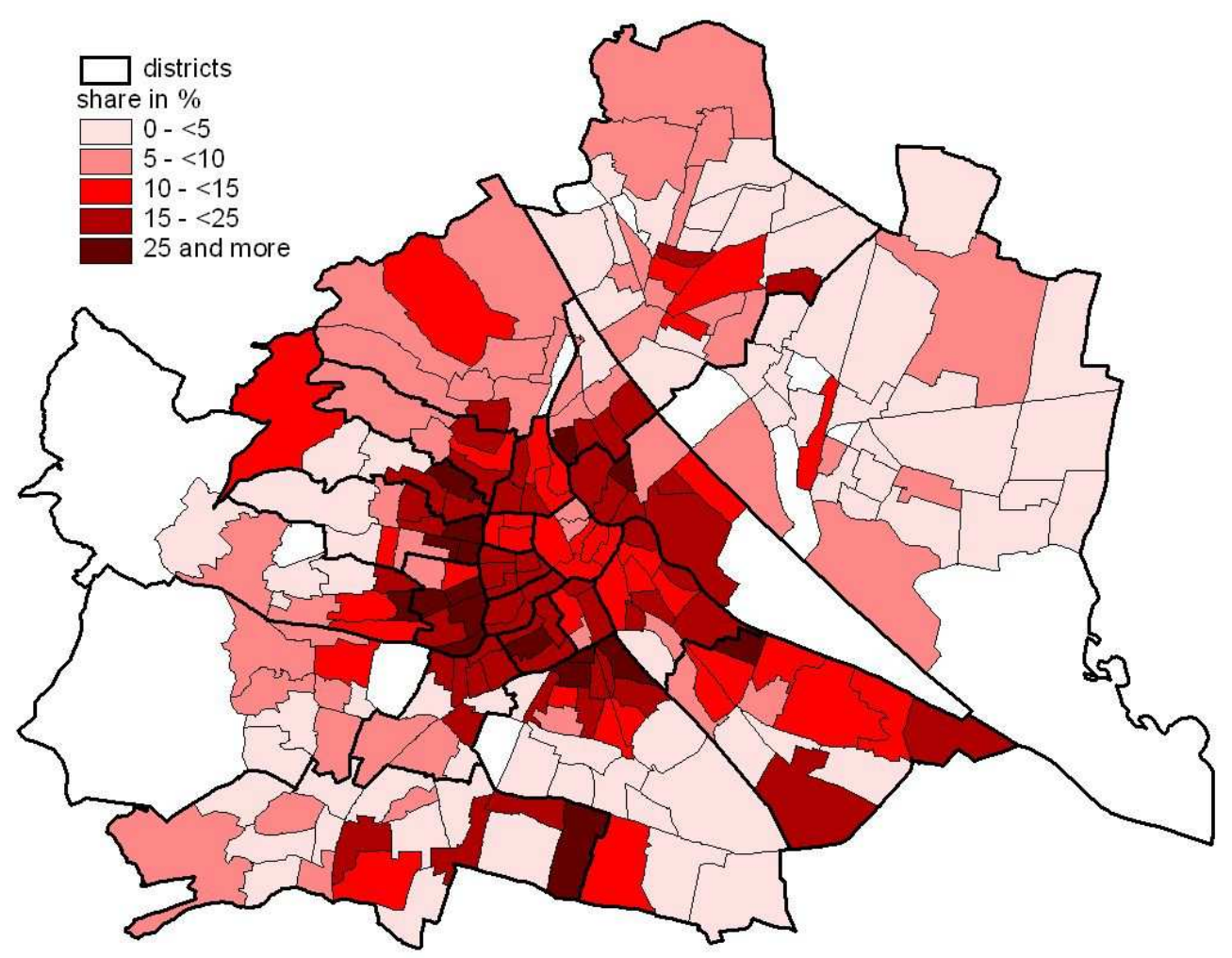

Source: Census 1991, cartography: U. Reeger.

proportion of foreigners is still higher in these areas than in the newly built-up areas in districts 21 and 22 on the other side of the Danube or in the South of Vienna.

A considerable proportion of the residents with migration background are still located in privately rented housing. In certain parts of the city $\left(5^{\text {th }}, 10^{\text {th }}, 16^{\text {th }}\right.$ and $17^{\text {th }}$ district), the share of flats with substandard infrastructure decreased steeply during the past 20 years, though is still twice as high as the overall city average. Since the end of the 1990s there has been a change in high-standard housing, the outcome of rising aspirations among the majority of immigrants. The intended duration of residence and the labour market situation play an important role in this process (Pflegerl \& Fernandez de la Hoz 2001). Access to public (council) housing was long restricted, and until the $1^{\text {st }}$ January 2006 most residents with third-country citizenship (except refugees with asylum status) could not make demands on public accommodation (except for the segment of emergency accommodations ("Notfallswohnungen"), about 2000 persons from 2000 to 2005). On the other hand, 97\% (2001) of the owners in the owneroccupied segment are Austrian citizens. 


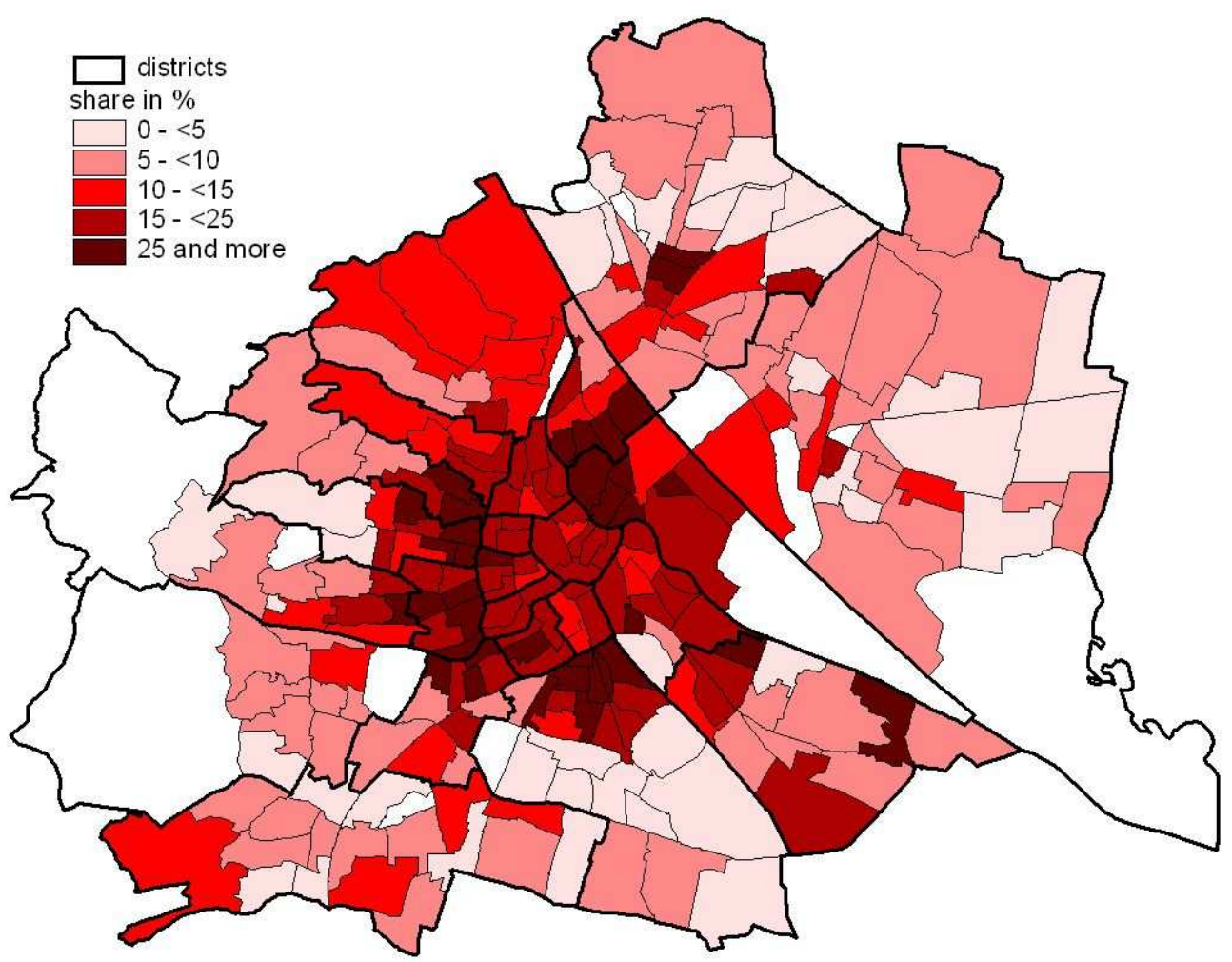

Source: Census 2001, cartography: U. Reeger.

As regards housing, the immigrant population is heterogeneous. "Elite" migrants from Western EU countries, North Americans as well as Japanese experts and diplomats usually live in the better-off areas of the "cottage" districts Döbling, Währing, or Hietzing, which are situated near the Vienna Woods, whereas migrants coming from former communist countries do not follow such a clear urban segregation pattern. The ethnic structure shows divergent patterns that depend on the social status of the migrant groups and their position on the labour market. The residential areas of the former "guest-workers," the Turkish group of which is shown in map 6, can be found in the densely built-up western districts. Here statistical units with up to $10.8 \%$ Turkish nationals constitute a pattern of increased density at the fringe of districts that since the 1970s have been the traditional areas of settlement of the guest-worker population. The overwhelming majority of the former guest-workers still live in areas where the housing stock stems from the $19^{\text {th }}$ century. The districts on the eastern side of the Danube are characterized by markedly lower proportions of persons of Turkish or Balkan descent. 
Map 6: Share of Turkish nationals in the total population, 2001

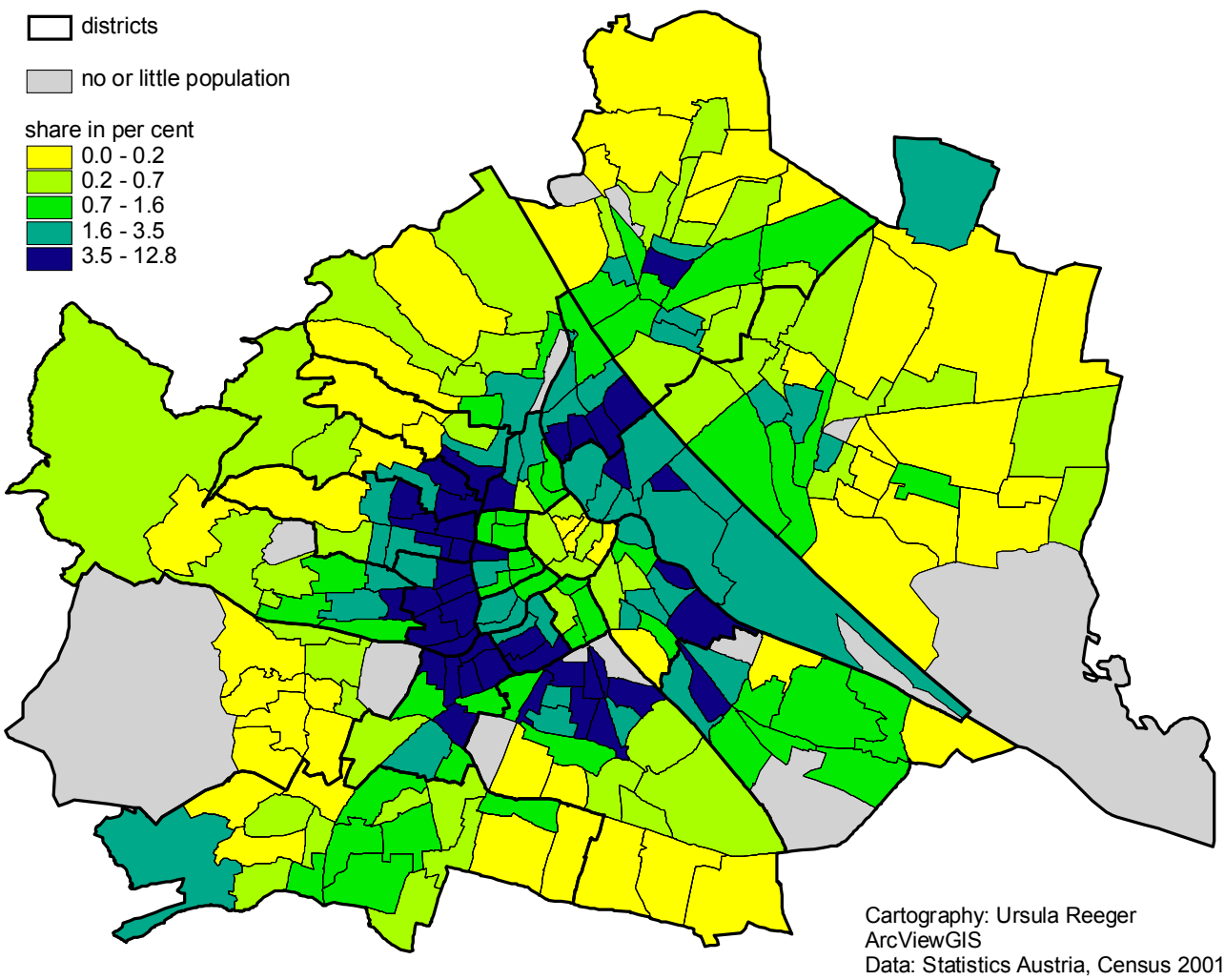

In 2001, about 25,000 migrants from the EU-15 member states lived in Vienna. These elite migrants usually inhabit the Viennese middle- and upper-class districts and thus show a different socio-spatial pattern of residence than the guest-workers. Especially the often privileged labour market position of Germans is mirrored in their residential patterns. One can see (cf. map 7) that the EU community is concentrated in the city and in the neighbouring bourgeois inner districts as well as along the western periphery where their share ranges from $3.0 \%$ to $10.8 \%$. These "cottage districts" are more sparsely populated and characterized by a housing stock consisting mainly of mansions and single-family houses with gardens.

It should be emphasized that, despite the fact that some ethnic segregation exists in Vienna, it is not a serious problem. Nowhere in the working-class districts is there a ghetto-like situation comparable to the situation in the larger cities of Great Britain or France (Kohlbacher \& Reeger 2007a). There are more social and integration problems in certain locations, where welfare recipients with or without migration background, drug or alcohol addicts, long-term unemployed, former homeless people and other marginalized persons life together in large council houses. 


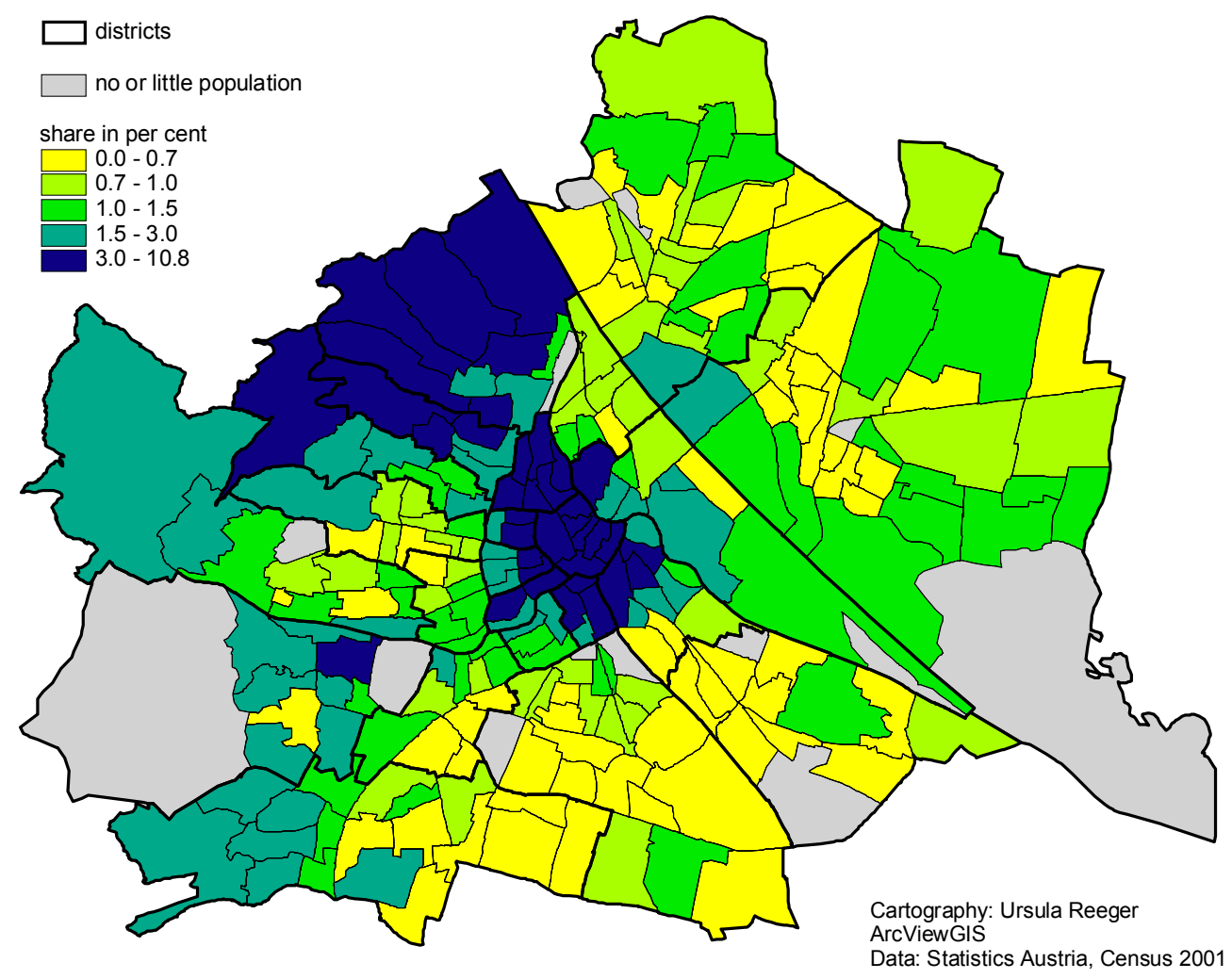

\subsection{Size and Quality of Foreign Household Flats}

There are also variations in housing standards between the various ethnonational groups. The housing standard of the elite migrants is usually even better than the Austrian average. Also, the stock of the middle-class migrants is well equipped. In 2001, 88\% of all Austrians lived in Category A flats (more than $30 \mathrm{sqm}$ ), but only $62 \%$ of the Turks and former Yugoslavs had such accommodations. Category D flats were occupied by $2.5 \%$ of Austrians, but by $18.5 \%$ of Turks and $27 \%$ of persons with Serbian-Montenegran citizenship. Naturalized migrants have better rates, but there is still a difference vis-à-vis indigenous Austrians. The size of the flat is a strong indicator. Inhabitants with a migration background also have a higher proportion of temporary rental contracts. Table 9 shows the differences between Austrians, elite migrants, and working-class immigrants concerning the housing standard (Kohlbacher \& Reeger 2003, 2007a). 
Map 8: Spatial distribution of the share of dwellings without basic amenities, 2001

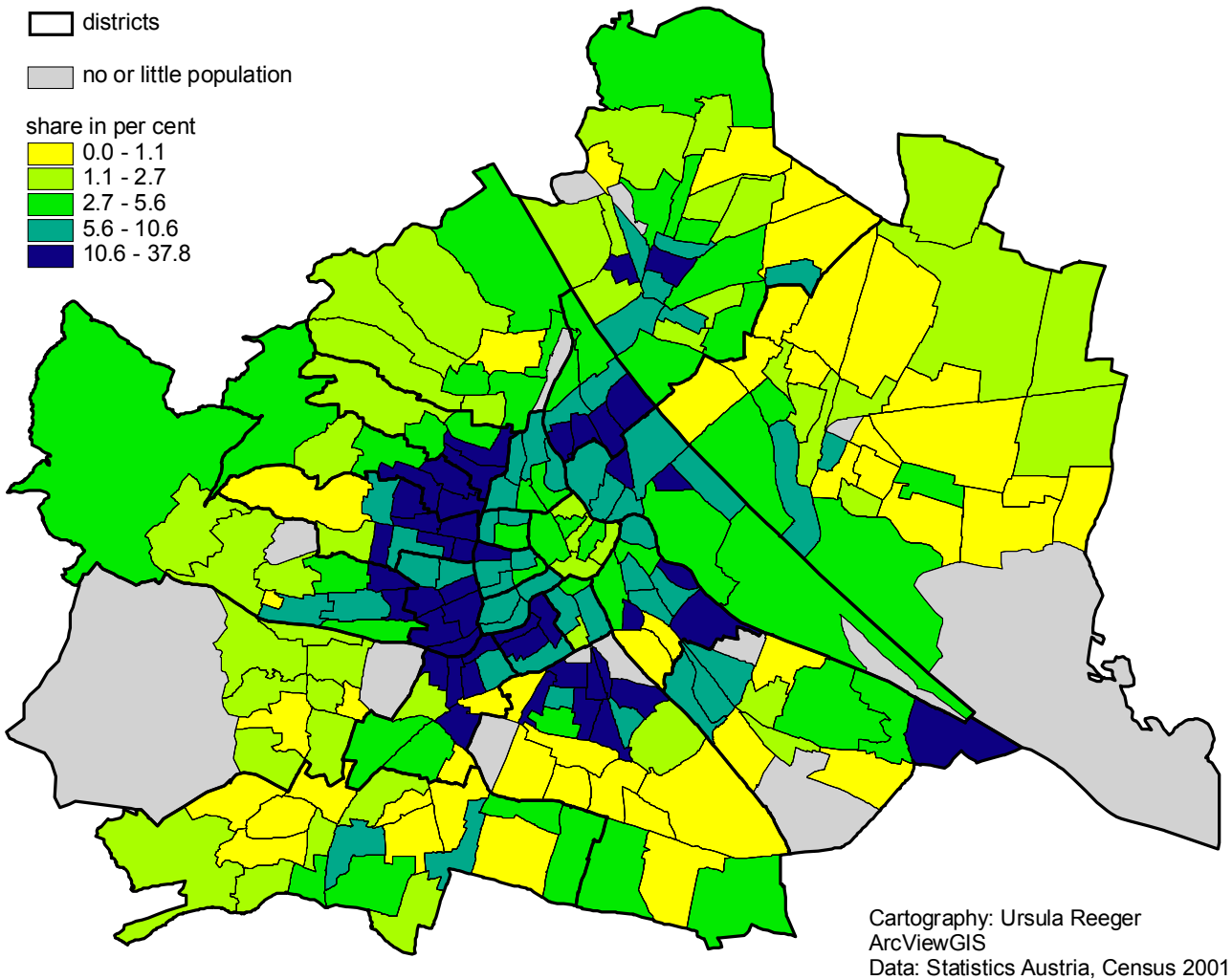

Table 9: Equipment in private residences according to citizenship of the household representative, Vienna 2001

\begin{tabular}{lrrrrr}
\hline & Cat. A & Cat. B & Cat. C & Cat. D & Total \\
\hline Austria & 89.9 & 4.7 & 1.2 & 4.2 & 100.0 \\
EU-15 & 92.0 & 4.3 & 0.6 & 3.2 & 100.0 \\
Former Yugoslavia & 56.3 & 10.3 & 1.6 & 31.8 & 100.0 \\
Turkey & 47.6 & 11.8 & 1.4 & 39.2 & 100.0 \\
Eastern Europe & 77.7 & 7.4 & 0.8 & 14.1 & 100.0 \\
Others & 82.2 & 6.8 & 0.8 & 10.2 & 100.0 \\
Total & 86.0 & 5.4 & 1.2 & 7.4 & 100.0 \\
Absolute numbers & $1,304,740$ & 81,757 & 18,200 & 112,952 & $1,517,649$ \\
\hline
\end{tabular}

Source: Statistics Austria - Housing situation of the population 2001, category A = with central heating, bathroom/shower and toilet inside, category $\mathrm{B}=$ with bathroom/shower and toilet inside, category $\mathrm{C}=$ toilet and water supply inside, category $\mathrm{D}=$ no toilet and/or no water supply inside. 


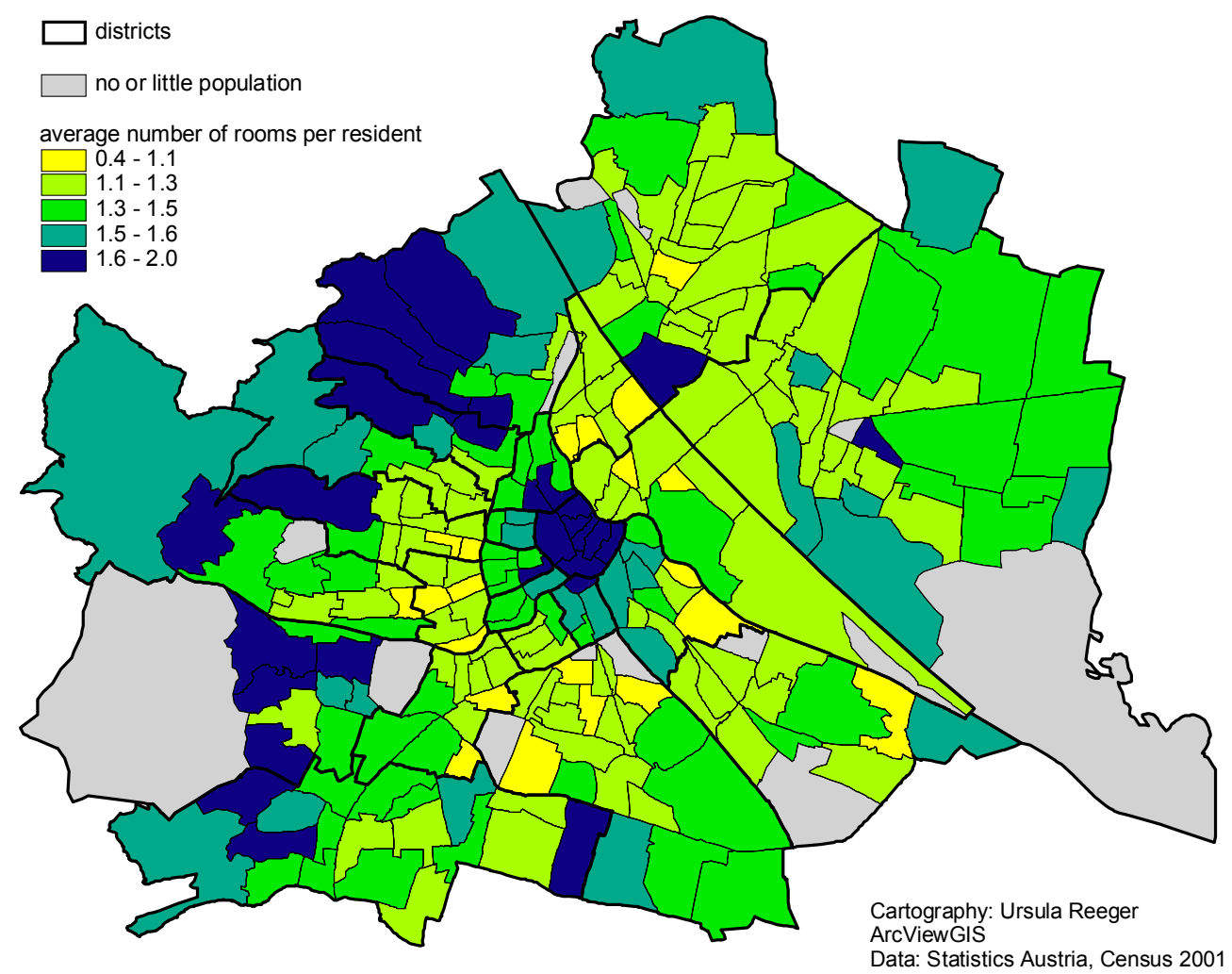

The Turkish households inhabit the highest proportion of substandard flats, followed by the former Yugoslavs with almost one-third. Migrants from EU-15 and Austrian household representatives could be found least often in flats of Category D. The Viennese housing average in Category D was $7.4 \%$ in 2001 and $86 \%$ in the best equipped segment. Austrian citizens and EU immigrants inhabited Category A flats at an above-average rate, followed by Eastern Europeans, 77\% of whom could be found in this housing segment. The competitive disadvantage of the Turkish households on the Viennese housing market is obvious: Only $47.6 \%$ have been successful in gaining a foothold in this category. The former Yugoslavs were represented to a greater extent in the best equipped apartments available on the housing market.

The indicator of the average number of rooms per resident also provides information about the distribution of the housing units in urban localities. From Map 9 we learn that the highest manifestations of this indicator are typical for the northwestern and southwestern cottage districts with their single-family homes as well as for the $1^{\text {st }}$ district and some areas bordering the city centre, where large apartments from the late 
$19^{\text {th }}$ century can frequently be found inhabited only by one or two elderly people. The average number of rooms per resident is the lowest in the working class areas with only 0.4 rooms available per person.

The number of rooms and the available living space are strongly interrelated variables. These indicators prove the competitive disadvantage of certain groups of the foreign residential population. The Turkish citizens are the group with the smallest living space at their disposal. More than half (55.3\%) of the persons living in Turkish households have less than $15 \mathrm{sqm}$ per capita; in comparison, in the households of former Yugoslavians the proportion was $35.6 \%$ in 2001. These figures lie five and three times, respectively, above the overall Viennese average of $11.3 \%$. Only $6.8 \%$ of the persons in households with an Austrian in them and 3.7\% of the persons in EU-15 households have less than $15 \mathrm{sqm}$. The living space supply, on the other hand, of immigrants from the "old" EU countries is excellent - even better than that of the Austrian citizens. About $15 \%$ of EU-15 citizens have at least $70 \mathrm{sqm}$ at their disposal and even more per capita. Among the Austrians the respective proportion is $9.3 \%$.

Migrant households are to a higher degree than Austrian households confronted with further deficits of housing quality, such as noise, environmental pollution due to traffic congestion, bad lighting conditions and deficiencies in thermal and sound insulation (Pflegerl \& de la Hoz 2001).

There are certain exclusionary mechanisms active on the housing market which discriminate against immigrants of certain ethno-national descent (Giffinger \& Reeger 1997, Kohlbacher \& Schwab 2002, Zuser 2001). Certain immigrant groups (e.g., Africans, Roma, Turks) are often confronted with "informal racism" (Gartner \& Müllner 1998: 54, ZARA 2008) on the private housing market, making apartment-hunting often much more complicated for them than for Austrians or EU-immigrants. These problems can also be observed in cases of financial illiquidity. The situation has improved since 2006, but even today not every family is able to gain a foothold in public housing. Temporary or short-term rental contracts may better correspond to the needs of short-term labour migrants, but such contracts are usually much more widespread even among long-term immigrants than among Austrian citizens. This may be seen as a further indicator of housing market discrimination of migrants and reinforces the insecurity in their lives.

A comparison of naturalized and nonnaturalized migrants (Kohlbacher \& Reeger 2008) shows that over the past years there has been an improvement in housing standards, an expansion of living space, a trend toward the public housing segment, and less segregation among naturalized immigrants. But again the variations between different immigrant groups are still present. Naturalized East-West migrants are more successful at improving their housing standards than Turks or former Yugoslavs. 


\section{Instruments to Improve the Housing Situation of Immigrants - Inputs and Outcomes}

In Vienna to date there exists a corporatist form of social-democratic urban governance. The administrative system experienced some changes during recent decades (Novy et al. 2001). But these changes are being challenged by increasing competition among cities, by suburbanisation, by environmental challenges, by the task of fighting social exclusion and by immigration. Since the 1970s there has been a shift from "government" to "governance", which means the flexibilisation of the institutional organisation of the public sector and a "shift from welfare to workfare" (Jessop 1994). The City Council has established more open planning procedures and new processes of participation. Competences were removed from the local government and shifted to public-private partnerships and private agencies.

The importance of equal housing opportunities for immigrants is often emphasized in the public discussion though not always mirrored in the reality of housing. Until recently, the definition of "good" housing standards was widely shared within European welfare states. There used to be a national consensus on dwelling size, layout, room functions, sanitary equipment, common facilities, etc. These housing norms have indeed continuously improved in the past, but they have nevertheless remained within a narrow range of the acceptable and the achievable. Migrants are facing the new housing problems that have opened up between more deregulated markets, on the one hand, and an increasingly stratified society, on the other hand. Housing policies now have to cope with a greater variety of supply and demand and a more diversified market.

\subsection{Public (Social, Communal) Housing}

In Vienna housing is understood as a part of its social-oriented city planning. There are no essential differences between general housing policies and those stipulated for vulnerable groups as immigrants, since the subject of housing is considered part of the social policies, where the central aim is to achieve equal rights and chances for all inhabitants regardless of their ethnic origin. The City of Vienna has several ways of influencing housing integration, and one of its top priorities is to provide affordable quality housing. Public housing is embedded in the context of urban planning and social policy. The city transferred the responsibility for the communal housing stock to the enterprise "Housing in Vienna" ("Wiener Wohnen"), which cooperates with MA 50 (the administration and maintenance of housing formerly owned by the City of Vienna).

Public housing plays a large role in Vienna as the communal stock consists of about 220,000 dwellings that are traditionally - and for political reasons - distributed over the whole city. The spatial pattern of communal housing is extremely widespread. Units with high proportions of residents in public housing (up to 98.8\%) are usually 
absent in the bourgeois inner districts, but they can frequently be found in the newly built-up areas at the urban fringe, where big housing estates have been erected since the $1970 \mathrm{~s}$. Thus, the $23^{\text {rd }}, 10^{\text {th }}$ and $11^{\text {th }}$ district in the south of Vienna, and the $21^{\text {st }}$ and $22^{\text {nd }}$ districts on the Eastern side of the Danube, are the areas in which extremely high concentrations of residents in communal housing are most frequently found.

Map 10: Share of residents in public housing, 2001

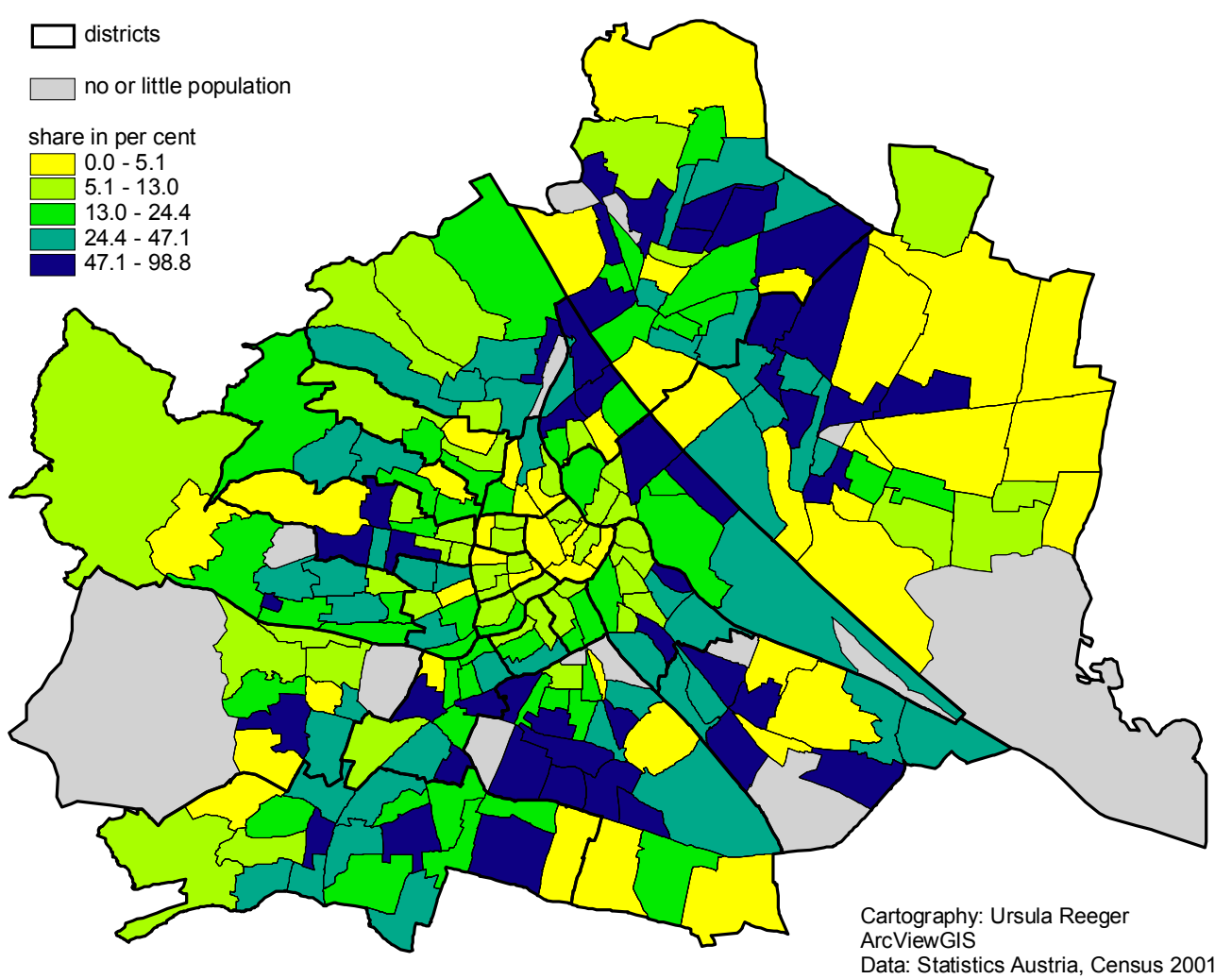

The city has installed an Infrastructure Commission to define in detail the conditions for subsidized housing projects, and subsidization is in fact one of the main instruments employed to intervene in the housing market. Because of a consistent policy of supporting public housing, Vienna long went relatively untouched by some problems typical for the housing sector of other European cities. Vienna's housing market is heavily influenced by public funds through housing construction subsidies and incentives.

In 1989 the housing subsidy system was organised on a federal basis. Since then nine different federal laws were passed to regulate the financial support for housing 
construction. To date, housing policy funds have mainly been provided by setting aside fixed percentages of certain kinds of tax revenue and by collecting housingspecific levies. The aim of the housing construction subsidy schemes is to build affordable housing for a large part of the population. Some of the advantages of the system of housing promotion are the more or less constant volume of subsidies and the concentration on the subsidization of the building costs of objects, mainly in form of long-term public loans with low interest rates. This type of subsidization opens up the possibility to reach a sustainable system. On the other hand, there are also disadvantages: the segmentation of the housing market, a lack of adaptation to changing conditions as well as big and unjustified differences in the level of rents (Fassmann \& Kohlbacher 2007).

The financing of public housing is based on a fixed, earmarked part of the income tax, the corporate tax, and the housing contributions, the latter of which is paid directly by all employed persons. These national tax revenues are distributed to the nine provinces according to a complex financial agreement. Despite several cuts in recent years, this method of financing still provides a secure base for the planning of public housing programs on a large scale, which would not be possible under strictly marketoriented housing policies (Förster 2002a, b).

The Viennese City Council still invests a lot of money in housing projects (Förster 2002a, 2002b, 2004), though in recent years the major part of new public housing has been carried out by non-profit housing associations. Most of the powerful housing associations (e.g. GEWOG, GESIBA, HEIMBAU, BWS, EBG, WIENER, WIENSÜD, WOHNBAU) belong (more or less) to the city. These associations are subject to the national Non-Profit Housing Act. In Vienna, they own and manage about 136,000 apartments, and even the major part of the owner-occupied apartments was built within the subsidized housing program. Non-profit housing associations enjoy tax relief and have to reinvest profits back into housing. Rents are regulated, the cost-rent covering only financing cost, the operating costs, and the 10 percent value-added tax. There is also a fixed maximum monthly net-rent for subsidized apartments in Vienna that cannot be exceeded. Low-income households are entitled to individual subsidies ensuring that they do not lose their apartments in case of illness or unemployment. All subsidized apartments are subject to certain income limits at the time of completion (Fassmann \& Kohlbacher 2007, Förster 2002a, b, Magistrat der Stadt Wien o.J.).

Creating diversified neighbourhoods has received increasing attention in Vienna since the 1990s. With increasing immigration flowing into social rental housing, the Viennese authorities tried to insert Austrians as well as "neo-Austrians" in order to prevent ethnic and socio-economic segregation as much as possible. The policy of ethnic mixing created houses characterized by social diversification. The older stock of the communal housing sector is not very popular among Austrian-born tenants (except the very poor, the socially "problematic" or elderly), and this has led to a process of selective migration ("Austrians out, neo-Austrians in"). 
The idea of mixing autochthonous and immigrant groups is welcomed in Vienna, among politicians as well as in the mass media, but not always among the persons concerned. Local policymakers generally accept that mixing is both necessary and profitable. In order to reach the target of mixing, since the mid-1990s the co-operative housing sector too attempted to adopt a strategy of selective distribution of vacant dwellings for distributing among migrant households. Contrary to the co-operative housing sector, for example, in many German cities, the local Viennese housing corporations at least officially did not formulate maximum percentages for the share of migrant tenants (Ludl 2003). Whether such measures ever existed unofficially remains an unanswered question because no information is available from the housing corporations.

In recent years (interethnic) conflicts in communal housing have become a problem of rising importance. In this respect considerable efforts are being undertaken to provide services to mediate conflicts in neighbourhoods, especially in the municipal housing sector, where there is a trend to perceive the "normal" conflicts of daily life (with regard to noise, dirt, etc.) differently when immigrants are involved. Since the summer months of 2008 so-called "nightwatchers" make inspection walkways at night in the communal housing blocks of some districts $\left(11^{\text {th }}, 12^{\text {th }}\right.$, etc.) to mediate in (noise) conflicts (Vienna online 19 May 2009). Now, it is planned to reinstate "concierges," who in the future should be better qualified and act as first-line advisers and mediators. From January to June 2009, 440 rental contracts were terminated by "Wiener Wohnen" resulting in the eviction of the tenants. 40 of these evictions were executed because of the renters' behaviour and 400 because of arrears of rent. Both causes are often also connected, and in many cases tenants with a migration background are affected. The number of terminations in the public housing sector has increased drastically compared with 2008, when 600 rental contracts were terminated during the whole year (Stuhlpfarrer \& Weiser, 9 July 2009 in the newspaper DiePresse).

\section{2 "Soft" Urban Renewal}

Decay of the building stock was a phenomenon caused by a lack of reinvestments in the decades leading up to the 1970s. More than 40,000 buildings with 300,000 flats in Vienna were built before 1918. Because of the specific situation of the housing market in Vienna in the post-war period, there was special emphasis put on the field of real estate. Small private properties were the rule and remained so. A comparison of Vienna with other cities all over Europe showed a unique mosaic of decaying and renewed buildings next to each other. A lack of transparency in the market caused investments to be made on a mostly random principle.

"Soft urban renewal" is the most important instrument for renovating such old building stock and improving the housing situation of thousands of households - and it is highly anti-segregative by nature. In 1974 the first area renewal office was 
founded, and the strategy of soft urban renewal was born. In 1984, there were more than 300,000 apartments (39\% of the total housing stock) categorised as being of insufficient standard, meaning without toilets and/or running water within the apartments. The City of Vienna decided both against demolition and construction of new urban areas, and against the displacement or compulsory re-housing of persons living in such areas. The actors were/are the municipality (MA 50 and Wohnfonds of the City of Vienna), Area Renewal Offices, private and public landlords, owners and tenants, who might be migrants or natives. The year 1989 provided more room for the program to decentralize Austrian housing policies to the provinces: The Vienna Housing Subsidization and Housing Renewal Law (WWFSG) was adopted (Lichtenberger 1990).

\section{Map 11: Areas with a necessity for renewal, 2006}

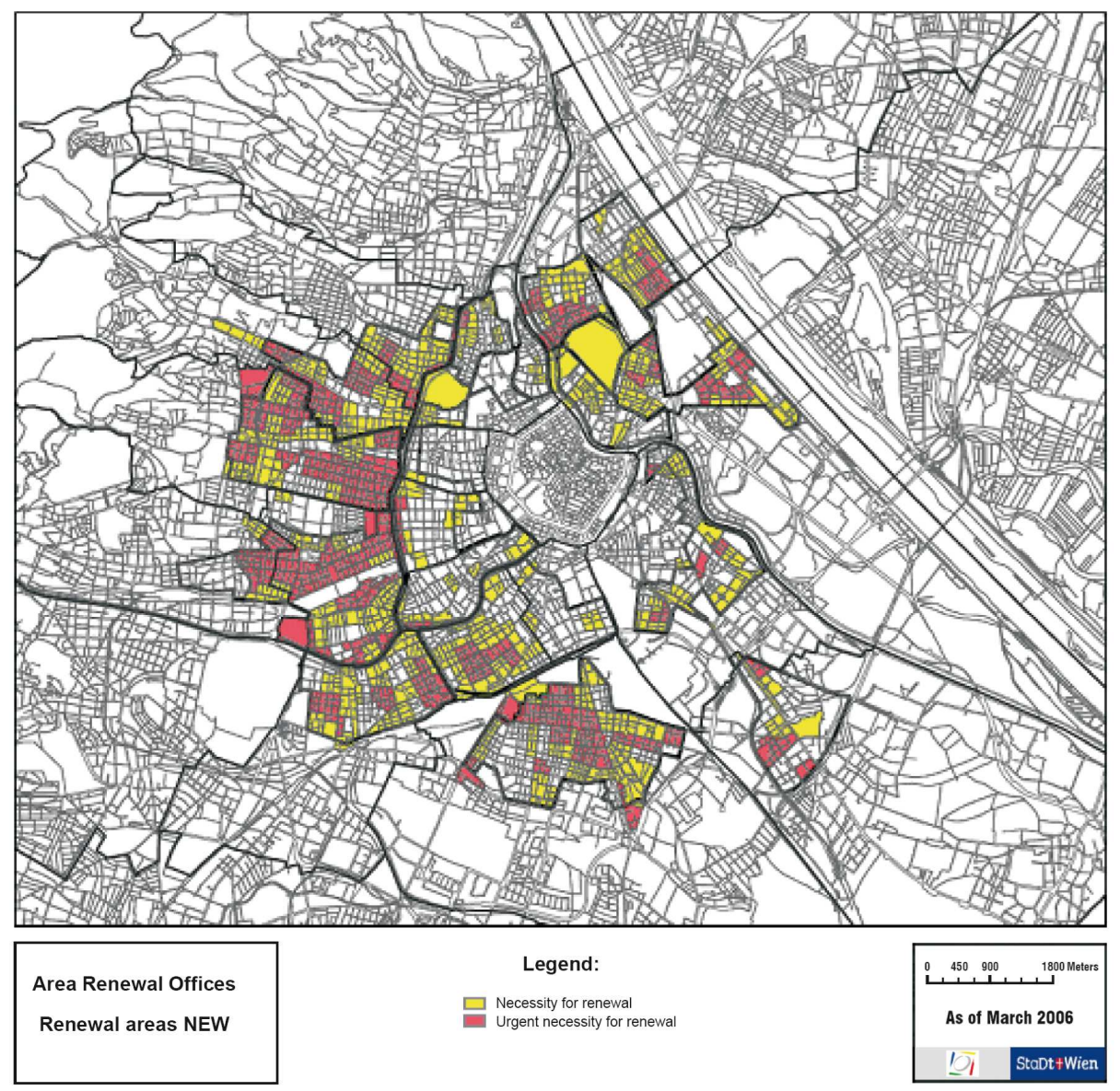

Source: City of Vienna, MD Stadtbaudirektion, Geschäftstelle Infrastruktur und Stadterneuerung. 
A decisive factor in the process of urban renewal is that it took on the interdisciplinary challenge to discover where social, economic, cultural, aesthetic, and ecological demands had to be taken into consideration. Urban renewal requires futureorientated, strategic, continual development reflecting the possibilities for the city as an evolving system. Soft urban renewal pursues the goal of linking affordable housing with economic use of resources, mixed use, and adaptation to the existing infrastructure. Reconversion and upgrading of the existing urban structure is counterposed to demolition and new building.

The Viennese model of urban renewal places residents in the foreground in order to minimise the hardships frequently caused by improvement activities. Renewal programs have to target those people already living in the area and consider their (financial) possibilities. The first aim must be to improve an area without evicting the residents. Owners and residents must be involved in the process. Of course, it is not only to the benefit of the immigrant population, but involves the whole population of the renewal areas. Great emphasis is placed on so-called base improvement, that is, on maintaining, improving, and modernising existing housing structures in coordination with residents. The main goals of soft urban renewal are (1) prioritising social criteria, (2) avoiding social segregation or gentrification, (3) avoiding forced change of ownership, and (4) creating affordable rehabilitated housing. An important instrument in this context is "Sockelsanierung", which means the renewal of inhabited buildings. It is based on a distribution of responsibilities between owner and tenants, tenants' participation, tenant-oriented modernisation schemes and substitute housing offers (Förster 2002a, b; Feigelfeld o.J.; Magistrat der Stadt Wien, Magistratsabteilung 5 2000). "Blocksanierung" (block improvement schemes) includes housing renewal and the improvement of public spaces and ecological measures.

Urban renewal is based on financial support from the City of Vienna for housing renovation programs. From the beginning of the program, 7,560 buildings applied for renewal with public assistance, 3,800 residential buildings with 181,000 apartments were approved, 2,160 buildings with 142,000 apartments were completed with public subsidies, one-sixth of the total housing stock - one of the world's leading tenant-oriented urban renewal programs; from 1984 to 2001 the category of "substandard" dwellings was reduced from approx. 320,000 (39\% of the total stock) to less than 125,000; the number of fully equipped apartments rose from about 328,000 to more than 715,000 . The amount of subsidies depends on the existing standard of apartments (maximum ca. 98\% of total building costs!). Allowances to low-income households are also granted. A controlled and limited rent increase is usually inevitable (Fassmann \& Kohlbacher 2007; Förster 2002 a and b, 2004).

Urban renewal uses an area-based approach. It also considers problems such as unemployment, crime rate, ethnic tensions, etc., as social problems that cannot be solved by building programs. Area-based renewal requires a decentralisation of decision-making, but at the same time an interdisciplinary approach to existing problems. From the spatial perspective a single-building-approach and area-oriented renewal exist 
side by side. It also implies improvement of the infrastructure such as open spaces and investing in public transport, and it tries to create new green spaces on small areas that are unused and in the courts. Conflict management is taken over by the local offices of the "Gebietsbetreuung" (= area renewal offices). In the years 1998, 2000 und 2002 soft urban renewal received an award as one of the 100 worldwide examples of Best Practices of UN-HABITAT.

Of course, there are no exact numbers available as to how many persons with migration background were involved in the renewal activities in urban renewal areas since the $1980 \mathrm{~s}$, but there is no doubt that this program is one of the most important initiatives of its kind in Europe. A great number of immigrants have benefited from the upgrading of the housing stock and the accompanying measures.

\subsection{Integrative Housing Projects}

Such projects are usually carried out by nonprofit housing associations (e.g. SOZIALBAU). They are oriented toward the integration of vulnerable groups such as migrants, the elderly, handicapped people, but there are also projects aimed specifically at women and at households without a car. Two projects oriented toward the integration of immigrants shall be mentioned here:

- "Interkulturelles Wohnen" (“Intercultural Housing"): This project is situated in the $21^{\text {st }}$ district (Satzingerweg) and consists of 51 flats rented by migrants (8\%) and by households with an immigration background (40\%) as well as by Austrians. Immigrants are integrated into neighbourhood relationships with Austrians. There are a lot of common areas used for common activities. The project is very successful but mostly accommodates economically well-off people (with or without a migration background) who had been selected from waiting lists. The project comprises the cooperation of the Housing Advice Centre Vienna and the Ministry of the Interior (Fund for Refugees) (Ulama 1997). In 2006, after 10 years, the tenant structure was as follows: $20 \%$ of the tenants were foreign born (from Hungary, Bosnia, Poland, GUS, Turkey, Iran, and the Philippines), $12 \%$ were living in binational relationships with Austrians, 68\% had been born in Austria. In 2006, a tenant survey was performed that proved an extremely high level of housing satisfaction and a very low fluctuation among the tenants.

- "Interethnische Nachbarschaft" ("Interethnic Neighbourhood"): This project, also called "In der Wiesen Nord" or "Globaler Hof", is situated in the $23^{\text {rd }}$ district, which is in general not a "migrant district". It was settled in 2000 by residents from 17 nations of whom about $60 \%$ were migrants. The housing project consists of four different blocks with 141 apartments. A common roof garden and rooms are included, also a sauna, a Turkish bath and a laundry room. The interactions between the tenants are very harmonious and the housing satisfaction is extraordinarily high (see Ludl 2003). 
Integrative housing projects can be classified as anti-segregation policy measures but still have a limited scale in terms of absolute numbers. Thus, their outcome is moderate compared with public housing or soft urban renewal. The projects in Vienna do not really influence existing patterns of segregation, but they are a visible step on the way toward mixing the autochthonous and the migrant population in districts with a low proportion of foreign residents.

\subsection{Basic Care for Asylum Seekers}

Vienna's Social Fund (Fonds Soziales Wien) ${ }^{15}$ is a tool for the implementation of the city's social policy. The Fund is also in charge of implementing care for asylum seekers and for those needy immigrants who cannot be returned to their home countries. It is also responsible for arranging housing for homeless people in general.

On 1 May 2004 an agreement was made between the Federal Government and the provinces concerning the responsibility for the provision of accommodation, food and other subsidies for asylum seekers. In 2007 an average of 6,500 asylum seekers monthly were provided with basic support. There is also basic care in housing. Quotas were laid down for each Austrian province.

\section{5 “Housing Turnstile” ("Wohndrehscheibe")}

Migrants with low incomes had little chance of finding long-term affordable housing. Subsidized non-profit rental housing was an option only for those who had permanent residency and those who were in the position to make the high down payments and pay the monthly rates. This was the situation when "Wohndrehscheibe" was initiated. "Wohndrehscheibe" is a part of the Housing Information System for the disadvantaged run by the Peoples' Aid of Austria ("Volkshilfe") and was carried out in cooperation with the workgroup "Better Housing for Foreigners" with the aim of improving the housing market for migrants in lower-income brackets. Since 2002 it has a working contract with Wohnservice-Wien GmbH (WWG, Vienna Housing Service). Thus, the project has now become an institution.

The Project is still in progress. The aim is to offer advice, guidance, and care to people with little income and very specific social problems in search of adequate housing. It does not support only migrants, but also disabled persons, single parents, women who were victims of domestic violence, etc. $75 \%$ of the clients do not have

15 Compare http://www.fsw.at/. The City defined the following tasks for it: improvement of health and health awareness among the Viennese population, support for persons in need with regard to basic needs including housing and work as well as medical, psychological, and social consultation, treatment, and care. 
Austrian citizenship. The issues at stake are manifold, including lack of information and funds, as well as discrimination on the part of landlords. Advice efforts are geared toward finding long-term, affordable, and acceptable housing solutions.

\section{$5 \quad$ Future Challenges}

In Vienna housing is understood as a part of a social-oriented city planning, and there is some consensus about the necessity of public intervention into immigration matters. Homelessness, ghettoization and other serious problems of housing integration of immigrants are counteracted by the City Council, and there is only little controversial discourse about these topics. An analysis of the present situation shows that Vienna has been successful in exercising its traditional role as the main engine of integration in Austria.

The two main instruments of housing integration are communal housing and urban renewal. It is obvious that Vienna's public housing policy is unique throughout Europe. Vienna's non-profit housing sector represents a multi-level system that for decades has successfully adapted to meet new challenges. Its primary aim is to offer comfortable contemporary housing in an attractive urban environment to all residents at affordable prices.

Concerning soft urban renewal, Vienna can be classified as the most successful European city in this field. Vienna also undertakes consultancy work in the context of urban renewal for other communities in Eastern Europe. The experience gained is applicable to other urban areas where redevelopment measures are being planned. Close contacts have been established between Vienna and the cities of Budapest and Bratislava. There is some conflict of interest in the districts built during the Founding Period with respect to the preservation of architecture on the one hand, and creation of new social, economic and housing-related developments on the other. These areas have a considerable integrative potential for new immigrants and are open to a mixture of new functions. Therefore, in Vienna the structures dating back to this era are treated with great sensitivity.

Vienna's migrant population has become more diverse during recent years. A numerically smaller, highly qualified elite group of migrants has started a spatial separation from the low-income sections of the migrant population. This is not a completely new trend but it was unquestionably intensified by the economic development of the last decades. There are major differences in the level of education, unemployment, and economic status between the districts and between different ethno-national groups, too. The residential patterns of the migrant population are strongly dependent on the structure and opportunities of the local housing market - and housing market structures change slowly. Now, as accessibility rules with respect to public housing stock have disappeared, economic resources can be seen as the most important factor when explaining the residential patterns of the various immigrants groups. 
Looking ahead, immigration will continue to capture the attention of the local policymakers for some time. Polarization tendencies within the agglomeration are perceptible, something closely connected to suburbanisation on the one hand and to immigration on the other. Urban sprawl is one of the megatrends in large cities all over Europe, and in Vienna too there is considerable demand for recreation areas and cheaper real estate. Some gentrification is also unavoidable. Thus, it should not always be considered an unwanted negative process, but also a sometimes necessary strategy to reverse a declining market position and to provide a social economic redifferentiation on the demand side and an investment for improving the neighbourhood. When offering better and more sustainable opportunities for neighbourhood renewal, cautious interventions are to be preferred to rash replacement. This implies the need for renovation-based approaches using resident involvement and self-support, so typical of the urban renewal program in Vienna.

\section{Bibliography}

Biffl, G. (2000), Zuwanderung und Segmentierung des österreichischen Arbeitsmarktes. Ein Beitrag zur Insider-Outsider-Diskussion, in K. Husa, C. Parnreiter \& I. Stacher (eds.), Internationale Migration. Die globale Herausforderung des 21. Jahrhunderts. HSKInternationale Entwicklung. Frankfurt am Main: 207-227.

Ebermann, E. (ed., 2007), Afrikaner in Wien zwischen Mystifizierung und Verteufelung. Erfahrungen und Analysen. $3^{\text {rd }}$ ed. Vienna.

Fassmann, H. \& J. Kohlbacher (2007), Case Study on Housing and Segregation of Migrants: Vienna, Austria. European Foundation for the Improvement of Living and Working Conditions (Eurofound) (ed.), CLIP Network (Cities for Local Integration Policy). Dublin.

Fassmann, H. \& R. Münz (1995), Einwanderungsland Österreich? Historische Migrationsmuster, aktuelle Trends und politische Maßnahmen. Vienna.

Fassmann, H., Kohlbacher, J. \& U. Reeger (eds., 2002), Zuwanderung und Segregation. Europäische Metropolen im Vergleich. Klagenfurt.

Feigelfeld, H. (o.J.), Partizipation in der Wiener Stadterneuerung (http://209.85.129.132/ search?q=cache: EQEuWU69LawJ:www.wohnbauforschung.at/Downloads/Feigelfeld_ Austausch_Paris-Wien_Partizipation_web.pdf+sanfte+stadterneuerung\&cd=17\&hl $=\mathrm{de} \& \mathrm{ct}=\mathrm{clnk} \& \mathrm{gl}=\mathrm{at})$.

Fernández de la Hoz, P. \& J. Pflegerl (2001), „Uns kann man alles verkaufen“. Verschlechterung der Wohnverhältnisse trifft MigrantInnen sehr, in P. Fernández de la Hoz \& J. Pflegerl, Die Bedeutung des Wohnens für Migrantenfamilien in Österreich. ÖIF-Materialiensammlung 8. Vienna. (http://www.oif.ac.at/presse/bzw/artikel.asp?Rubrik=3\&ID_Art=1\&BZWArtikel=527).

Förster, W. (2002a), 80 years of public housing in Vienna, in W. Förster (ed.), Public housing - Innovative Architecture, Harry Seidler. Munich: Neue Donau Housing Estate. 
Förster, W. (2002b), Sozialer Wohnbau in Wien: 80 Jahre Erfolg und Herausforderung, Mag. Dr. Wolfgang Förster, MA 50. (http://www.gebietsbetreuung.wien.at/htdocs/sozialeswohnen.html).

Förster, W. (2004), Urban Renewal - The Viennese Way, in R. Sterk \& H. Eisenberger (eds.), Vienna's Gentle Renewal. Vienna: Brandstätte, 47-71.

Gartner, B. \& A. Müllner (1998), Wohnsituation von Ausländer/innen in Graz. Studie im Auftrag des Ausländerbeirates der Stadt Graz. Graz.

Giffinger, R. \& U. Reeger (1997), Turks in Austria: Backgrounds, Geographical Distribution and Housing Conditions, in S. Özüekren \& R. van Kempen (eds.), Turks in European Cities: Housing and Urban Segregation. Utrecht: 41-66.

Gunz, J. \& J. Weidenholzer (1999), Soziale Lage der AusländerInnen in Oberösterreich. Perspektiven einer Integrationspolitik. Studie im Auftrag der oberösterreichischen Landesregierung 45. Linz.

Jessop, B. (1994), Post-Fordism and the state, in A. Amin (ed.), Postfordism. A reader. Oxford: 251-279.

John, M. (2003), Von der Anwerbung der „Gastarbeiter“ bis zu den Folgen der Globalisierung: Arbeitsmigration in Österreich, in M. John \& M. Lindorfer (eds.), migration - eine zeitreise nach europa. kursiv 10-1/2/03: 5-26.

Kohlbacher, J. \& U. Reeger (2003), Die Wohnsituation von AusländerInnen in Österreich, in H. Fassmann \& I. Stacher (eds.), Österreichischer Migrations- und Integrationsbericht. Demographische Entwicklungen - sozioökonomische Strukturen - rechtliche Rahmenbedingungen. Klagenfurt: 87-108.

Kohlbacher, J. \& U. Reeger (2005), Residential segregation, housing market and immigrants, in M. Lucinda Fonseca \& J. Malheiros (eds.), Social Integration and Mobility: Education, Housing and Health Estudos para o Planeamento Regional e Urbano 67, Universidade de Lisboa: $20-48$.

Kohlbacher, J. \& U. Reeger (2007a), Wohnverhältnisse und Segregation, in H. Fassmann (ed.), 2. Österreichischer Migrations- und Integrationsbericht, Klagenfurt: 305-327.

Kohlbacher, J. \& U. Reeger (2007b), Wohnungsgröße und Wohnungskosten von AusländerInnen in Österreich, in H. Fassmann (ed.), 2. Österreichischer Migrations- und Integrationsbericht, Klagenfurt: 328-330.

Kohlbacher, J. \& U. Reeger (2008), Staatsbürgerschaftsbonus beim Wohnen? Eine empirische Untersuchung der Unterschiede zwischen eingebürgerten und nichteingebürgerten Zuwanderern/-innen hinsichtlich ihrer Wohnsituation in Wien. ISR-Forschungsberichte 35. Vienna.

Kohlbacher, J. \& D. Schwab (2002), Ausländer auf dem Wiener Wohnungsmarkt - Strukturen, Probleme und aktuelle Entwicklungen, in H. Fassmann, J. Kohlbacher \& U. Reeger (eds.), Zuwanderung und Segregation. Europäische Metropolen im Vergleich. Klagenfurt: 197208.

Lichtenberger, E. (1990), Stadtverfall und Stadterneuerung. Beiträge zur Stadt- und Regionalforschung 10. Vienna.

Ludl, H. (ed., 2003), Das Wohnmodell inter-ethnische Nachbarschaft. Vienna: Springer. 
Magistrat der Stadt Wien (ed.) (o.J.), UN-HABITAT Best Practices Programm. (http://www.wien.gv.at/stadtentwicklung/bestpractices/pdf/best_pract_handout.pdf).

Magistrat der Stadt Wien, Magistratsabteilung 5, Wohnbauförderung, Wohnhaussanierung, Wohnungsverbesserung und Aufsicht über die gemeinnützigen Bauvereinigungen (ed.) (2000), Sanfte Stadterneuerung, Best Practice UN-Habitat 1996 - Update 2000. (http://www.bestpractices.at/main.php?page=vienna/best_practices/housing/urban_renewal \&lang $=\mathrm{de})$.

Novy, A., Redak, V., Jäger, J. \& A. Hamedinger (2001), The end of Red Vienna - recent ruptures and continuities in urban governance, European Urban and Regional Studies, 8 (2): 131-144.

Pflegerl, J. \& P. Fernandez de la Hoz (2001), Die Bedeutung des Wohnens für Migrantenfamilien in Österreich. Österreichisches Institut für Familienforschung (ÖIF), Materialiensammlung 8. Vienna.

Reeger, U. (2002), Trautes Heim? - Einige Anmerkungen zur Wohnsituation von „Ausländern“ in Wien, in P. Döllmann \&. R. Temel (eds.), Lebenslandschaften. Zukünftiges Wohnen im Schnittpunkt zwischen privat und öffentlich. Frankfurt am Main, New York: 120-130.

Stuhlpfarrer, M. \& U. Weiser (Die Presse, 9 July 2009), Die Folgen der „scharfen Hausordnung“, (http://diepresse.com/home/panorama/oesterreich/493919/index.do).

Ulama, M. (1997), Gemeinschaft ohne Windfang, Interkulturelles Wohnen. Satzingerweg 81, 1210 Wien. (http://www.nextroom.at/building_pdf.php?building_id=2640\&article_id=3764).

ZARA (Zivilcourage und Antirassismusarbeit) (ed., 2005-2008), Rassismus reports 20052008. Vienna.

Zuser, P. (2001), Schwerpunktthema Wohnen. Wohnsituation von MigrantInnen in Österreich, in Wiener Integrationsfonds (ed.), MigrantInnen in Wien 2000. Vienna: 38-49. 